Jurnal Riset Agama

Volume 1, Nomor 1 (April 2021): 167-176

https://journal.uinsgd.ac.id/index.php/jra

\title{
Penentuan Awal Puasa Ramadhan dalam Perspektif Hadis
}

\author{
Lisa Istianah \\ Department of Hadith Science, Faculty of Usuluddin \\ UIN Sunan Gunung Djati Bandung \\ lisaistianah12@gmail.com
}

\begin{abstract}
The purpose of this study is to discuss the hadith about fasting. This research method uses qualitative research through literature study with content analysis. The results and discussion of this study include general views of fasting, hadiths about fasting, and determining the beginning of Ramadan fasting. The conclusion of this study is that the hadith about fasting is found in various books, including Sunan an-Nasa'i, Sahih Muslim, Sunan Abu Dawud, Sunan Ibn Majah, and Jami 'at-Tirmidhi. Determining the start of Ramadan fasting can be done in two ways, namely the rukyat method and the reckoning method.
\end{abstract}

Keywords: Fasting, Hadith, Hisab, Rukyat

\begin{abstract}
Abstrak
Tujuan penelitian ini adalah membahas hadis tentang puasa. Metode penelitian ini menggunakan jenis penelitian kualitatif melalui studi pustaka dengan analisis isi. Hasil dan pembahasan penelitian ini meliputi pandangan umum puasa, hadis tentang puasa, dan penentuan awal puasa Ramadhan. Kesimpulan penelitian ini adalah hadis tentang puasa terdapat di berbagai kitab, di antaranya Sunan an-Nasa'i, Shahih Muslim, Sunan Abu Dawud, Sunan Ibnu Majah, dan Jami' at-Tirmidzi. Penentuan awal puasa Ramadhan bisa dilakukan dengan dua cara, yaitu metode rukyat dan metode hisab.
\end{abstract}

Kata Kunci: Hadis, Hisab, Puasa, Rukyat 
Jurnal Riset Agama, Volume 1, Nomor 1 (April 2021): 167-176

Lisa Istianah / Penentuan Awal Puasa Ramadhan dalam Perspektif Hadis

\section{Pendahuluan}

Ibadah puasa pada bulan Ramadhan merupakan suatu kewajiban umat Islam diseluruh dunia (Rezi, 2016). Penentuan awal bulan Islam atau yang biasa kita sebut dengan bulan qamariyyah merupakan suatu hal yang penting bagi ummat Islam (Musyafa', 2020). Sesuai dengan perhitungan hari pada bulan qamariyyah yang berkisar pada angka 29 dan 30, membuat hari pada bulan Ramadhan terkadang juga bervariasi setiap tahunnya (Rezi, 2016). Hal ini berbeda dengan kalender Masehi yang berkisar di angka 30 dan 31 kecuali bulan Februari (Rezi, 2016). Selain itu, perhitungan kalender Masehi berpatokan pada perhitungan rotasi matahari terhadap bumi, sedangkan kalender qamariyyah berpatokan pada rotasi bulan terhadap bumi (Rezi, 2016). Namun, penentuan awal dan akhir bulan Ramadhan selalu terjadi perselisihan paham yang berujung pada perbedaan awal puasa dan awal hari raya (Rezi, 2016). Oleh karena itu, pemahaman mengenai dalil-dalil tentang puasa sangat penting untuk diketahui (Rezi, 2016).

Sejumlah pakar telah melakukan penelitian berkenaan dengan puasa sebagaimana dalam tinjauan pustaka penelitian ini. Antara lain Idris, M.A. (2020), Judul “Konstruksi Puasa Waqi'ah," Penerbit Institut Agama Islam Negeri Surakarta. Penelitian ini menggunakan metode kualitatif. Hasil dan pembahasan penelitian ini adalah tentang pelaksanaan puasa Waqi'ah, pelaku dan proses pemberian ijazah puasa Waqi'ah, faktor yang menyebabkan puasa Waqi'ah dilaksanakan, serta pengaruh puasa Waqi'ah bagi para pelakunya. Penelitian ini menyimpulkan bahwa puasa Waqi'ah merupakan puasa yang berbeda dengan puasa lainnya, dimulai dari maksud dan tujuan para pelaku hingga waktu pelaksanaan serta amalan-amalan yang dibaca (Idris, 2020). Marahamid, A. R. (2020), Judul "Telaah Hadis tentang Doa Buka Puasa dan Pendapat Ulama Fiqh." Penelitian ini mengggunakan dua metode, yaitu metode takhrij al-hadis dan metode naqd al-hadis. Hasil dan pembahasan penelitian ini adalah doa buka puasa di kalangan ulama khususnya ulama empat madzhab fikih tidak ada yang sama. Penelitian ini menyimpulkan bahwa hadis tentang buka puasa yang populer dibaca oleh umat Islam terdapat sebanyak lima hadis, yaitu riwayat Abu Daud, Al-Baihaqi, AlTabrani, Ibn Abi Syaibah, dan Al-Daraqutni (Marahamid, 2020). Rezi, M. (2016), Judul "Pemahaman Hadis-hadis Rukyat Hilal dan Relasinya dengan Realita Isbat Ramadhan di Indonesia" Penelitian ini merupakan penelitian pustaka dengan mencari dan mengkaji teks-teks hadis terkait permasalahan penentuan awal dan akhir bulan puasa. Hasil dan pembahasan penelitian ini adalah rukyat hilal sebagai penanda utama puasa Ramadhan dan hari raya, satu bulan dua puluh sembilan hari, cukupnya rukyat hilal oleh beberapa 
orang, hilal terlihat pada siang hari dan setiap wilayah memiliki rukyatnya sendiri telah jelas ketentuannya di dalam hadis-hadis Nabi. Penelitian ini menyimpulkan bahwa rukyat hilal merupakan metode atau cara untuk menentukan awal dan akhir bulan Ramadhan (Rezi, 2016).

Berbagai penelitian terdahulu berharga dalam penyusunan kerangka berpikir penelitian ini. Istilah puasa dalam bahasa Arab disebut dengan AsShiyam yang memiliki arti sama dengan kata Al-Imsak; yakni menahan dari melakukan sesuatu atau meninggalkannya (Mufaizin, 2018). Dalam sejarah umat manusia, puasa sudah dikenal sejak zaman kuno, baik untuk terapi pengobatan maupun ritual keagamaan tertentu (Mufaizin, 2018). Masyarakat Indonesia berpuasa setelah melewati metode rukyat, yakni penentuan awal dan akhir puasa Ramadhan (Rezi, 2016). Sabda Nabi saw tentang puasa terdapat dalam kitab hadis yang diriwayatkan oleh Abu Daud, Muslim, AlBukhary, At-Turmudzi, An-Nasa'i, Ibn Majah, Ahmad bin Hanbal, Malik, dan Al-Darimy dalam kitab Al-Shawm (Puyu, 2010). Hadis tentang puasa dari segi sanad dan matan berkualitas shahih lidzatih (Puyu, 2010). Puasa wajib dilaksanakan ketika hilal sudah terlihat (Puyu, 2010). Masih sering ada orang yang melaksanakan ibadah puasa Ramadhan sebelum masuknya Ramadhan (Puyu, 2010). Mengetahui awal Ramadhan adalah dengan cara melihat hilal melalui mata kepala atau dengan perhitungan (Puyu, 2010) Penentuan awal Ramadhan dengan melihat hilal atau perhitungan dikenal dalam ilmu falak dengan nama hisab ru'yat (Puyu, 2010).

Berdasarkan paparan di atas, penulis berusaha menyusun formula penelitian, yaitu rumusan masalah, pertanyaan penelitian, dan tujuan penelitian (Darmalaksana, 2020). Rumusan masalah penelitian ini adalah terdapat penjelasan hadis tentang puasa. Pertanyaan utama penelitian ini ialah bagaimana penjelasan hadis tentang puasa. Sedangkan pertanyaan secara terperinci yaitu bagaimana pandangan umum tentang puasa, bagaimana penjelasan hadis tentang puasa, dan bagaimana penentuan awal dan akhir puasa. Tujuan penelitian ini yakni menjelaskan hadis tentang puasa. Penelitian ini diharapkan memiliki manfaat bagi pengayaan khazanah pengetahuan Islam.

\section{Metode Penelitian}

Penelitian ini merupakan jenis kualitatif melalui studi pustaka dengan analisis isi (Gunawan, 2013).

\section{Hasil dan Pembahasan Penelitian}

Hasil dan pembahasan penelitian di bawah ini. 
Jurnal Riset Agama, Volume 1, Nomor 1 (April 2021): 167-176

Lisa Istianah / Penentuan Awal Puasa Ramadhan dalam Perspektif Hadis

\section{Pandangan Umum Puasa}

Rukun Islam yang keempat adalah puasa. Puasa wajib dilakukan oleh umat Islam yang telah memenuhi ketentuan-ketentuannya. Puasa yang dimaksud adalah puasa Ramadhan (Andy S. ). Ibadah puasa dilakukan sejak zaman Nabi Musa, bukan hanya di zaman Rasulullah saw. meskipun di dalam kitab Taurat, Jabur, dan Injil tidak ada ketentuannya. Dahulu, Nabi Musa pernah melaksanakan puasa selama 40 hari. Kaum Yahudi saat ini pun melaksanakan puasa, yaitu puasa selama satu minggu untuk mengenang hancurnya Jerusalem dan mengambilnya kembali, puasa di hari ke sepuluh pada bulan ke tujuh menurut perhitungan mereka, dan berpuasa sehari semalam (Hamka, 2015). Tujuan melaksanakan puasa tidak lain untuk memperbaiki diri dari kesalahan-kesalahan yang telah diperbuat dan tidak melaksanakan kesalahan itu lagi (Andy S. ).

Secara umum puasa berarti menahan. Maksudnya, menahan dari bicara. Namun, yang dimaksud dalam hal ini adalah berniat menahan diri sejak terbitnya fajar sampai terbenamnya matahari dari segala sesuatu yang membatalkannya (Al-Faif, 2014). Puasa sangat erat kaitannya dengan tiga hal berikut ini. Pertama, menahan diri dari lapar dan haus. Kedua, menahan diri dari hubungan seksual. Dan ketiga, menahan diri dari penglihatan, pendengaran, atau ucapan yang tidak baik. Oleh karena itu, puasa didefinisikan dengan menahan diri dari segala sesuatu yang membatalkan (Agama, 2007).

Puasa didefinisikan dengan menahan diri dari makan, minum, dan berjimak yang disertai dengan niat. Definisi ini dipaparkan oleh Ibn Kasir (ArRifa'i, 2011). Puasa bertujuan untuk mensucikan dan membersihkan diri dari keburukan-keburukan dan akhlak yang rendah. Sifat rakus dan sombong pun bisa disembuhkan dengan berpuasa selain dapat disembuhkan dengan sholat melalui ruku. Hal tersebut membuat manusia tahu akan siapa dirinya. Setelah itu mereka akan sadar dan tidak akan membuat kerusakan yang disebabkan oleh kerakusan dan kesombongannya (Ar-Rifa'i, 2011).

Awalnya, puasa dilakukan setiap bulan selama tiga hari. Kemudian hal itu di nasakh dengan puasa pada bulan Ramadhan. Puasa dapat mempersempit gerak setan dan membendung syahwat yang merupakan awal dari munculnya segala bentuk kemaksiatan. Hal ini dipaparkan dalam Tafsir Jalalain (al-Mahalli, 2010). Menurut Buya Hamka, puasa dapat menjadi pengendali dua syahwat yang terdapat di dalam diri manusia, yaitu syahwat seks dan syahwat perut. Tujuannya agar kemauan diri dan nafsunya dapat 
dikekang dan dikendalikan. Sehingga apabila pengendalian tersebut berhasil maka derajatnya sebagai manusia akan terangkat (al-Mahalli, 2010).

Ditinjau dari berbagai segi, puasa memiliki banyak manfaat. Namun, banyak orang yang belum menyadari dan memahaminya. Seandainya orangorang tahu akan manfaat dari puasa, maka mereka akan tekun dalam melaksanakan puasa Ramadhan. Karena puasa merupakan salah satu alat ampuh untuk mencapai kehidupan yang diridhai Allah (Daradjat, 1996).

Manusia akan memperoleh hikmah dan manfaat dari berpuasa, di antaranya meningkatkan keimanan dan ketakwaan kepada Allah, menjaga kesehatan mental, mempertinggi budi pekerti, dan mempererat hubungan keluarga (Daradjat, 1996). Selain itu, terdapat nilai-nilai pendidikan yang diperoleh dari berpuasa, di antaranya melatih manusia dalam mengendalikan hawa nafsu, melatih kesabaran, membentuk pribadi yang amanah dan takwa serta menumbuhkan sikap persatuan dan kesatuan sesama muslim (El-Sutha, 2014).

\section{Hadis-hadis Mengenai Puasa}

Terdapat sejumlah hadis berkaitan dengan puasa. Berikut tabel tematik hadis mengenai puasa.

Tabel 1. Tema Hadis Puasa

\begin{tabular}{|c|c|c|c|}
\hline No. & Tema Hadis & $\begin{array}{l}\text { Kitab dan Nomor } \\
\text { Hadis }\end{array}$ & Periwayat \\
\hline 1 & $\begin{array}{l}\text { Perbedaan pada manshur } \\
\text { pada hadis rubai }\end{array}$ & $\begin{array}{l}\text { Sunan An-Nasa'i No. } \\
2099\end{array}$ & An-Nasa'i \\
\hline 2 & $\begin{array}{l}\text { Wajibnya puasa Ramadhan } \\
\text { karena melihat hilal dan } \\
\text { berbuka karena melihat } \\
\text { hilal }\end{array}$ & $\begin{array}{l}\text { Shahih Muslim No. } \\
1800\end{array}$ & Muslim \\
\hline 3 & Jika bulan tidak terlihat & $\begin{array}{l}\text { Sunan Abu Dawud } \\
\text { No. } 1981\end{array}$ & Abu Dawud \\
\hline 4 & $\begin{array}{l}\text { Setiap kawasan } \\
\text { mempunyai hilal tersendiri }\end{array}$ & $\begin{array}{l}\text { Jami' At-Tirmidzi No. } \\
629\end{array}$ & At-Tirmidzi \\
\hline 5 & $\begin{array}{l}\text { Menghitung hilal Sya'ban } \\
\text { dan Ramadhan }\end{array}$ & $\begin{array}{l}\text { Jami' At-Tirmidzi No. } \\
623\end{array}$ & At-Tirmidzi \\
\hline 6 & $\begin{array}{l}\text { Jika hilal telah terlihat di } \\
\text { wilayah lain dengan selisih } \\
\text { satu malam }\end{array}$ & $\begin{array}{l}\text { Sunan Abu Dawud } \\
\text { No. } 1985\end{array}$ & Abu Dawud \\
\hline 7 & $\begin{array}{l}\text { Jangan puasa sebelum } \\
\text { waktunya }\end{array}$ & $\begin{array}{l}\text { Jami' At-Tirmidzi No. } \\
620\end{array}$ & At-Tirmidzi \\
\hline
\end{tabular}


Jurnal Riset Agama, Volume 1, Nomor 1 (April 2021): 167-176

Lisa Istianah / Penentuan Awal Puasa Ramadhan dalam Perspektif Hadis

\begin{tabular}{|c|l|l|l|}
\hline 8 & $\begin{array}{l}\text { Kesaksian satu orang } \\
\text { melihat hilal dianggap } \\
\text { cukup, dan perbedaan } \\
\text { masalah ini. }\end{array}$ & $\begin{array}{l}\text { Sunan An-Nasa'i No. } \\
2087\end{array}$ & An-Nasa'i \\
\hline 9 & $\begin{array}{l}\text { Perbedaan pada Yahya bin } \\
\text { Abi Katsir tentang berita } \\
\text { Abu Salmah }\end{array}$ & $\begin{array}{l}\text { Sunan An-Nasa'i No. } \\
2109\end{array}$ & An-Nasa'i \\
\hline 10 & Kesaksian melihat hilal & $\begin{array}{l}\text { Sunan Ibnu Majah No. } \\
1643\end{array}$ & Ibnu Majah \\
\hline 11 & $\begin{array}{l}\text { Kesaksian satu orang laki- } \\
\text { laki untuk hilal Ramadhan }\end{array}$ & $\begin{array}{l}\text { Sunan Abu Dawud } \\
\text { No. 1993 }\end{array}$ & Abu Dawud \\
\hline
\end{tabular}

Tabel 1. merupakan hadis-hadis mengenai puasa. Penentuan awal bulan Ramadhan dapat dilakukan dengan dua cara. Pertama dengan cara rukyat, kedua dengan cara hisab. Penentuan awal bulan Ramadhan dengan cara rukyat dilakukan secara langsung dengan melihat hilal pada saat terbenamnya matahari di akhir bulan. Apabila hilal belum terlihat dapat disebabkan oleh dua faktor, pertama karena cuaca pada saat itu mendung dan kedua karena hilal masih berada di bawah ufuk. Sedangkan penetapan awal bulan Ramadhan dengan cara hisab dilakukan dengan melihat tingginya hilal pada saat matahari terbenam. Tanggal satu Ramadhan atau bulan baru terjadi apabila hilal sudah berada diatas ufuk (Hajar, 2015).

\section{Penentuan Awal Puasa Ramadhan}

a. Metode Rukyat

Metode rukyat sudah digunakan sejak zaman Rasulullah Saw. dan para sahabat untuk menentukan waktu-waktu ibadah seperti waktu shalat, puasa, dan ibadah haji (Sabda, 2019). Rukyatul hilal pada masa Rasulullah dan beberapa geneasi setelahnya dilakukan dengan melihat bulan sabit tanpa alat bantu apapun, yakni dengan mata telanjang.

Secara bahasa rukyat artinya melihat. Sedangkan secara istilah rukyat adalah kegiatan melihat kemunculan hilal (bulan sabit yang pertama kali tampak) yang dilakukan saat menjelang terbenamnya matahari atau waktu magrib. Kegiatan tersebut dilakukan pada tanggal 29 bulan yang sedang berlangsung menggunakan mata telanjang ataupun alat bantu seperti teleskop (Rezi, 2016). Apabila hilal terlihat, maka malam itu ditetapkan sebagai tanggal 1 bulan baru. Namun, apabila hilal belum terlihat maka bulan berlangsung digenapkan menjadi 30 hari, kemudian magrib di hari berikutnya ditetapkan sebagai tanggal 1 bulan baru (Sabda, 2019).

Rasulullah Saw. bersabda: 
Jurnal Riset Agama, Volume 1, Nomor 1 (April 2021): 167-176

Lisa Istianah / Penentuan Awal Puasa Ramadhan dalam Perspektif Hadis

$$
\text { العدة يكون تسعة وعشرون ويكون ثلاثين فأذا رأيتموه فصوموا وأذا رأيتموه فأفطروا فأن غم عليكم فأكملوا }
$$

Artinya: Satu bulan itu ada yang dua puluh sembilan hari, dan ada pula yang tiga puluh hari. Apabila kamu melihat hilal maka berpuasalah dan apabila kamu melihatnya maka berbukalah. Jika penglihatanmu tertutup (oleh awan) maka sempurnakanlah bilangan itu (Marpaung, 2018).

Berdasarkan keadaan masyarakat Madinah, rukyat memiliki pengertian melihat dengan mata telanjang. Pengertian tersebut sangat cocok dengan masyarakat Madinah karena hadis-hadis tentang rukyat muncul di Madinah. Namun, jika dilihat berdasarkan keadaan masyarakat Mekah, pengertian melihat dengan mata telanjang tidak cocok dengan keadaan masyarakat Mekah. Karena pada saat itu masyarakat Mekah sudah mengenal ilmu pengetahuan dan astronomi (Seff, 2007).

Pengertian rukyat bisa diketahui menggunakan dua teori. Pertama, alibratu bi umumi al-lafzhi la bi hususi as-sababi yaitu rukyat tidak hanya diartikan sebagai melihat dengan mata telanjang. Sehingga dalam konteks ini tidak hanya melibatkan masyarakat Madinah tetapi masyarakat Mekah pun termasuk di dalamnya. Kedua, al-ibratu bi hususi as-sababi la bi umumi al-lafzhi yaitu rukyat diartikan sebagai melihat dengan mata telanjang (Seff, 2007).

Setiap negara Islam memiliki kriteria Imkan ar-ru'yah yang berbedabeda. Di Indonesia, kriteria yang digunakan adalah sebagaimana yang telah disepakati oleh MABIMS (Menteri-menteri Agama Brunei Darussalam, Indonesia, Malaysia, dan Singapura). Adapun kriteria tersebut yaitu: a) Tinggi bulan minimum dua derajat; b) Jarak bulan-matahari minimum tiga derajat; dan c) Umur bulan saat maghrib minimum delapan jam.

\section{b. Metode Hisab}

Secara bahasa, hisab berasal dari kata حسب - بحسب - حسابا yang artinya perhitungan. Istilah hisab biasa digunakan dalam ilmu falaq (astronomi) untuk mengetahui posisi matahari dan bulan terhadap matahari (Supriatna, 2007). Secara istilah, hisab berarti penentuan awal bulan Qamariyah berdasarkan peredaran bulan mengelilingi bumi. Melalui metode hisab, penentuan awal bulan dapat diketahui jauh sebelumnya dan tidak tergantung pada terlihatnya hilal pada saat terbenamnya matahari menjelang tanggal satu bulan baru (Muslifah, 2020). Allah berfirman dalam QS. Yunus: 5:

"Dia-lah yang menjadikan matahari bersinar dan bulan bercahaya dan ditetapkan-Nya manzilah-manzilah (tempat-tempat) bagi perjalanan bulan itu, supaya kamu mengetahui bilangan tahun dan perhitungan (waktu)." 
Metode hisab terbagi kedalam dua bagian, yaitu hisab urfi dan hisab hakiki. Dalam hisab urfi, dilakukan dengan cara mengambil simpulan ratarata lamanya umur bulan Qamariyah. Metode ini dilakukan untuk menentukan umur bulan 30 hari atau 29 hari. Sedangkan dalam hisab hakiki, apabila hilal telah terlihat di ufuk timur pada waktu maghrib, maka dipastikan sudah masuk tanggal satu bulan baru.

\section{Kesimpulan}

Konsep penentuan awal puasa menurut hadis yang menjadi tujuan pembahasan dalam penelitian ini disajikan menurut susunan kerangka berpikir yang mencakup pandangan umum tentang puasa, hadis tentang puasa, dan penentuan awal puasa Ramadhan. Berdasarkan pandangan umum tentang puasa diketahui bahwa puasa adalah menahan diri dari segala sesuatu yang membatalkannya mulai dari terbit fajar hingga terbenam matahari. Puasa bertujuan membersihkan dan mensucikan diri dari akhlak-akhlak yang buruk. Puasa memiliki banyak manfaat, di antaranya meningkatkan kesehatan mental, meningkatkan keimanan dan ketakwaan kepada Allah, mempertinggi budi pekerti, dan mempererat hubungan keluarga. Hadis tentang puasa terdapat di berbagai kitab, di antaranya Sunan an-Nasa'i, Shahih Muslim, Sunan Abu Dawud, Sunan Ibnu Majah, dan Jami' at-Tirmidzi. Penentuan awal puasa Ramadhan bisa dilakukan dengan dua cara, yaitu metode rukyat dan metode hisab. Dengan demikian, ketika umat Islam hendak berpuasa Ramadhan harus sudah memasuki bulan Ramadhan agar menjadi amal ibadah yang tidak sia-sia. Diharapkan hasil penelitian ini bermanfaat untuk menambah setitik pengayaan khazanah pengetahuan Islam tentang hadis puasa. Diakui penelitian ini memiliki keterbatasan dalam penyusunan kerangka berpikir dalam pembahasan hadis tentang puasa sehingga dibutuhkan penelitian yang lebih komprehensif, integral dan mendalam.

\section{Daftar Pustaka}

Agama, D. (2007). Materi Pokok Pendidikan Agama Islam (. Jakarta: Universitas Terbuka.

Al-Faif, S. (2014). Al-Wajiz Fi Figh As-Sunnah. Beirut: Beirut publishing. al-Mahalli, I. d.-S. (2010). Tafsir Jalalain, terj. Bahrun Abu Bakar. Bandung: Sinar Baru Algensindo. 
Jurnal Riset Agama, Volume 1, Nomor 1 (April 2021): 167-176

Lisa Istianah / Penentuan Awal Puasa Ramadhan dalam Perspektif Hadis

Andy, S. (n.d.). Hakikat Puasa Ramadhan dalam Perspektif. Jurnal Ibn Abbas, 1-17.

Andy, S. (n.d.). Hakikat Puasa Ramadhan dalam Perspektif Tasawuf (Tafsir Q.S Al-Baqarah: 183). Jurnal Ibn Abbas.

An-Nasa'i. (n.d.). Sunan an-Nasa'i Juz 1. Bairut: Darul Fikr.

Ar-Rifa'i, M. (2011). Ringkasan Tafsir Ibnu Kasir, terj. Budi Permadi. Jakarta: Gema Insani.

Bashori, M. (2012). Pergulatan Hisab Rukyat di Indonesia (Analisis Posisi Keyakinan Keagamaan dalam Penentuan Awal Bulan Kamariah. Semarang: IAIN Walisongo.

Daradjat, Z. (1996). Puasa Meningkatkan Kesehatan Mental. Jakarta: CV. Ruhama. Darmalaksana, W. (2020). Metode Penelitian Kualitatif Studi Pustaka dan Studi Lapangan. Pre-Print Digital Library UIN Sunan Gunung Djati Bandung. El-Sutha, S. H. (2014). Tiada Bulan Seindah Ramadhan. Jakarta: Kalam Mulia. Gunawan, I. (2013). Penelitian Kualitatif. Pendidikan, 143.

Hajar. (2015). Analisa Hadis Penerapan Awal Bulan Ramadhan dan Shawal. Ijtihad, Jurnal Wacana Hukum dan Kemanusiaan, 275-294.

Hamka. (2015). Tafsir Al-Azhar. Jakarta: Gema Insani.

Idris, M. A. (2020). Konstruksi Puasa Waqi'ah. Jurnal Living Hadis, UIN Sunan Kalijaga Yogyakarta, 17-39.

Marahamid, A. R. (2020). Telaah Hadis tentang Doa Buka Puasa dan Pendapat Ulama Fiqh. Al-Azhar Islamic Law Review, 98.

Marpaung, W. (2018). Madzhab Negara: Alternatif Solusi terhadap Perbedaan Penentuan Awal Bulan Qamariyah di Indonesia. Jurnal Ilmu Syari'ah, Perundang-undangan dan Ekonomi Syari'ah, 121-131.

Mufaizin. (2018). Kearifan Syariat dan Hikmah dalam Puasa. Al-Insyiroh Volume 2, Nomor 2, 103-127.

Muslifah, S. (2020). Upaya Menyikapi Perbedaan Penentun Awal Bulan Qamariyah di Indonesia. Azimuth: Journal of Islamic Astronomy, 74-100.

Musyafa', M. A. (2020). Penentuan Awal Bulan Islam Menurut Mazhab Syafi'i. El-Falaky, 158-169.

Puyu, D. (2010). Implikasi Penentuan Awal dan Akhir Puasa. al-Hikmah, 271287.

Rezi, M. (2016). Pemahaman Hadis-hadis Rukyat Hilal dan Relasinya dengan Realita Isbat Ramadhan Di Indonesia. ALHURRIYAH : Jurnal Hukum Islam, 109-124.

Sabda, A. (2019). seri 02 Ilmu Falak Rumusan Syar"I dan Astronomi. Bandung: Persis Pers. 
Jurnal Riset Agama, Volume 1, Nomor 1 (April 2021): 167-176

Lisa Istianah / Penentuan Awal Puasa Ramadhan dalam Perspektif Hadis

Seff, S. (2007). Hisab-Rukyat sebagai Metode Penetapan Awal Bulan Qomariyah: Kajian atas Metode Penetapan Awal Puasa dan Hari Raya di Indonesia. Al-Banjari, 153-188.

Supriatna, E. (2007). Hisab Rukyat dan Aplikasinya Buku Satu. Bandung: Refika Aditama. 